\title{
Effect of Microwave Pretreatment on the Oil Yield of Mango Seeds for the Synthesis of a Cocoa Butter Substitute
}

\section{Elham Momeny*, Shahrooz Rahmati and Nazaruddin Ramli}

School of Chemical Science \& Food Technology, Faculty of Science \& Technology, University Kebangsaan Malaysia, 43600 Bangi, Selangor, Malaysia

\begin{abstract}
The effect of microwave (MW) radiation on mango seeds (MS) was investigated as a pretreatment process prior to oil extraction by solvents. Pretreatments were carried out at two levels of power ( $300 \mathrm{~W}$ and $450 \mathrm{~W}$ ) and for four radiation times $(180,130,90$ and 70 s). It was observed treatment at $300 \mathrm{~W}$ for 180 s lead to improved extraction efficiency so that oil yield of MS increased to $8.9 \%$ which was higher compared to the conventional method. The quality characteristics (e.g. peroxide value, acid value) and oil composition was clarified. MSO profile can be suitable to synthesize cocoa butter substitute (CBS) through the enzymatic interesterification with cocoa butter (CB) in three different ratios of (MSO:CB) : 60:40, 50:50 and 40:60. The slip melting point, saponification value and iodine value of the $40: 60$ blend were $28.75^{\circ} \mathrm{C}, 186.8$ and 36.3 respectively. The melting behavior of the $40: 60$ blend was close to cocoa butter, compared to the other enzymatic and non-enzymatic blends. The thermal behavior of the 40:60 blend showed that crystallization occurred between $18.73^{\circ} \mathrm{C}$ and $-52.55^{\circ} \mathrm{C}$, with a $\Delta H_{\mathrm{c}}$ of $89.74 \mathrm{~J} / \mathrm{g}$, and melting between $-8.72^{\circ} \mathrm{C}$ and $45.56^{\circ} \mathrm{C}$. The fusion maximum was $24.79^{\circ} \mathrm{C}$ for the $\alpha$ and $\beta$ polymorphic forms, and the fusion enthalpy was $77.04 \mathrm{~J} / \mathrm{g}$. The 40:60 MSO:CB blend had a profile similar to that of $\mathrm{CB}$.
\end{abstract}

Keywords: Microwave pretreatment; Cocoa butter substitute; Interesterification; Mango seed oil; Cocoa butter

\section{Introduction}

Analytical research on the utilization of microwave and dielectric heating started in the late 1970s and was first applied by the food industry. Microwave heating is known as an exceptional alternative energy to other thermal applications due to its effective volumetric heat production. Microwave operations have extensive applications in food technologies such as oil extraction, pasteurization, sterilization, baking, blanching, cooking, drying, and thawing of different food products [1]. In addition, within different conventional pretreatments including de-hulling, size reduction, breaking, grinding, thermal treatment (cooking) and enzymatic hydrolysis, the utilization of irradiation microwave as a pretreatment method enables to save energy and reduce processing times due to delivering energy directly to materials through molecular interaction with the electromagnetic field, so generating heat throughout the volume of the material occurs and makes possible to obtain rapid and uniform heating of materials. By using microwave irradiation as pretreatment procedure before extraction of oil from the seeds, the higher extraction yield can be achieved due to cell membrane rapture; generating permanent pores and transferring oil from permeable cell walls $[2,1]$. Penetration of microwaves within a food sample can be determined by chemical composition, electrical and physical properties, heating patterns, quality control and microbial inactivation [1]. There is not much information in the literature about the application of microwave radiation as a pretreatment for mango seed and its effect on the microstructure of the substrate, extraction yield and quality of oil.

Conventional vegetable oil extraction is carried out by pressing or solvent extraction [2]. Solvent oil extraction is usually used for seeds that contain low amounts of fat $(<20 \%)$, such as soybeans [1]. Three main disadvantages of conventional Soxhlet extraction include first, the extraction time is long; second a large amount of solvent is used; in addition, $\mathrm{n}$-hexane, the main component of commercial hexane, is listed as No. 1 on the list of 189 hazardous air pollutants by the US Environmental Protection Agency parameters lead to wide criticism of the conventional soxhlet extraction method [3]. Since efficiency of conventional extraction for oil seeds with low fat/oil content are not deniable, utilization of microwave pretreatment enable to improve conventional extraction through decrease solvent consumption and times processing.

Cocoa butter (CB) is a unique fat that is highly appreciated because of its physicochemical characteristics but limited supply and large demand lead to a quite high price [4]. Transformation of lowcost fats and oil triacyglycerid through enzymatic interestrification to develop cocoa butter substitute or equivalent has been carried out. The substitute which is a type of fat has no similar chemical composition but show same fusion profile [5].

Mango is a significant tropical fruit and is gaining increasing relevance in the world. The mango seed is the major waste of mango processed from factories, and it is a promising source of edible oil because its fatty acid and triglyceride profile is similar to that of cocoa butter triacylglycerol. Mango seed oil (MSO) can provide nutritional benefits such as improving blood glucose levels, lowering LDL cholesterol, enhancing weight loss and improving cardiovascular and bone health $[6,7]$.

Therefore, the objective of present study was to evaluate effects of microwave pretreatment on yield and physicochemical characteristics of MSO to be used for producing cocoa butter substitute.

\section{Principals and Mechanism of Microwave}

Microwaves are non-ionizing electromagnetic waves of frequency between $300 \mathrm{MHz}$ to $300 \mathrm{GHz}$ with positioning in between the $\mathrm{X}$ - ray and infrared rays in the electromagnetic spectrum.

Science microwaves present two major purposes, communication

*Corresponding author: Elham Momeny, School of Chemical Science \& Food Technology, Faculty of Science \& Technology, University Kebangsaan Malaysia, 43600 Bangi, Selangor, Malaysia, E-mail: elham_mn81@yahoo.com

Received June 01, 2012; Accepted July 15, 2012; Published July 15, 2012

Citation: Momeny E, Rahmati S, Ramli N (2012) Effect of Microwave Pretreatment on the Oil Yield of Mango Seeds for the Synthesis of a Cocoa Butter Substitute. J Food Process Technol 3:164. doi:10.4172/2157-7110.1000164

Copyright: (c) 2012 Momeny E, et al. This is an open-access article distributed under the terms of the Creative Commons Attribution License, which permits unrestricted use, distribution, and reproduction in any medium, provided the original author and source are credited. 
and as energy vectors. Microwaves compose up of two oscillating perpendicular field's i.e. electric field and magnetic field and the former is responsible for heating.

Conventional heating which depends on conduction-convection phenomenon can lead to loss of heat energy to the environment, otherwise, in case of microwaves, heating happens in a targeted and selective manner with no heat being lost to the environment as the heating occurs in a closed system. The principle of heating in microwave is established on its direct impact with polar materials/solvents and is regulated by two phenomenon's: ionic conduction and dipole rotation, which in most cases occurs concurrently. Ionic conduction ascribe to the electrophoretic migration of ions under the control of the changing electric field. Dipole rotation indicates rearrangement of the dipoles of the molecule with the rapidly altering electric field. Heating is influenced only at a frequency of $2450 \mathrm{MHz}$ and changing the electric component of the wave occurs $4.9 \times 104$ times per second. In the frequency less than $2450 \mathrm{MHz}$, the electrical component changes at a much lower speed so the molecules get sufficient time to align itself with the electric field, therefore no heating occurs [8].

\section{Materials and Methods}

Fresh and mature mangos were collected from a local market in Malaysia. Cocoa butter (CB) was obtained from Klkepong Sdn Bhd, Port Klang, Malaysia. Immobilized 1,3-specific lipase from Thermomyces lanuginose, under the name Lipozyme TL IM (Novozymes A/S, Bagsvaerd, Denmark), was used in this study.

\section{Sample Preparation}

All the fruits were peeled, and their pulp was completely removed. The kernels were washed and air dried before they were chopped into small pieces. The moisture content was then reduced to below $10 \%$ in an oven with a gentle flow of air at $50^{\circ} \mathrm{C}$ for $72 \mathrm{~h}$. The dried kernels were ground in a hammer mill with a 100 mesh sieve to a fine powder and stored in a closed dark glass bottle. The powder was stored at $4^{\circ} \mathrm{C}$ until utilization; this sample was applied for conventional soxhlet extraction [9].

\section{Microwave Pretreatment Methodology}

Shelled mango seeds (15 g) were arranged in a single layer on a Pyrex petri dish ( $9 \mathrm{~cm}$ diameter), so that a total of $90 \mathrm{~g}$ of samples was distributed among six petri dishes that were placed in the middle of the turntable plate of a microwave oven (model 71 B Samsung, Malaysia). According to preliminary tests, the stabilizing microwave treatments were controlled by two variables: power and radiation time. Two levels of power $(300 \mathrm{~W}$ and $450 \mathrm{~W})$ and four radiation times (180, 130, 90 and $70 \mathrm{~s}$ ) were investigated in this study. Each of the six treatments was replicated three times. The samples were then cooled down to an appropriate temperature for extraction by a Soxhlet extractor. The samples were oven-dried at $60^{\circ} \mathrm{C}$ for $24 \mathrm{~h}$ before extraction to reach final constant weight [2].

\section{Oil Extraction and Purification}

Oil extraction from the dried mango seed meal was performed in a Soxhlet apparatus using hexane as a solvent. This process was carried out for $6 \mathrm{~h}$ at $140^{\circ} \mathrm{C}$; after solvent removal, the oil was kept away from light and air at $5^{\circ} \mathrm{C}$ before analysis and further processing. Mango seed oil from mature fruits was purified using an adaptation of the Wesson method. In this process, crude fat was dissolved in petroleum ether at a ratio of 1:5(W/V). Potassium hydroxide (14\%) was added to dissolve the fat ( $1 \mathrm{ml} \mathrm{KOH}$ per gram of dissolved fat) and was vigorously stirred for $3 \mathrm{~min}$; 50\% ethyl alcohol was added at a ratio of 1:2.5 (W/V) during stirring. The mixture was then left to stand until separation. The ether phase contained the natural fat, and the soap alcohol phase was extracted again with ether. The ether extracts were processed in a rotavapor to recover the purified fat. The purified fat was kept in a freezer $\left(5^{\circ} \mathrm{C}\right)$ away from light until processing [9].

\section{Enzymatic Interestrification}

The interesterification reactions, based on the Macrae (1983) method, were carried out in a batch system. Mango seed oil (MSO) and cocoa butter (CB) were mixed at three different ratios: 60:40, 50:50, and 40:60. The reactions occurred in presence of n-hexane solvent and lipase ( $10 \mathrm{w} / \mathrm{w} \%$ of substrate). The mixtures were stirred at $100 \mathrm{rpm}$ at a temperature of $35^{\circ} \mathrm{C}$ for 3 days in an orbital incubator. Anhydrous $\mathrm{Na}_{2}$ $\mathrm{SO}_{4}$ was used to dry the organic layers, and the enzyme was removed using filter paper. Interesterified products were obtained [10].

\section{Fatty Acid Composition}

The fatty acid composition of mango seed oil was determined using gas chromatograph equipped with a flame ionization detector (FID) and a glass column ( $3 \mathrm{~m} \mathrm{x} 3 \mathrm{~mm}$ i.d.) that was packed with 5\% DEGC on $80 / 100$ chromosorb. The temperatures of the column and detector were $180^{\circ} \mathrm{C}$ isothermal and $270^{\circ} \mathrm{C}$, respectively. The flow rates of $\mathrm{N}_{2}$, $\mathrm{H}_{2}$ and air were $20 \mathrm{ml} / \mathrm{min}, 75 \mathrm{ml} / \mathrm{min}$ and $0.5 \mathrm{ml} / \mathrm{min}$, respectively. Analysis of the standard mixture of FAME under identical conditions was carried out prior to running the sample [11]

\section{Thermal Profile}

Purified samples of CB and the MSO:CB mixture in a ratio of 40:60 were analyzed using differential scan calorimetry (DSC). Nitrogen gas was flowing at a rate of $20 \mathrm{~mL} / \mathrm{min}$. The instrument was calibrated with indium (melting point $=156.6^{\circ} \mathrm{C} ; \Delta H_{\mathrm{f}}=28.45 \mathrm{~J} / \mathrm{g}$ ). A thermobalance was used to weigh out 5 -mg samples in aluminum SFI capsules (precision of $\pm 0.1 \mathrm{mg}$ ) that were hermetically sealed. Before determining the thermal profiles, $\mathrm{CB}$ and the blend were tempered at $90^{\circ} \mathrm{C}$ for $5 \mathrm{~min}$ then cooled at $24^{\circ} \mathrm{C}$ for $24 \mathrm{~h}$; the samples were stored for 15 days at $5^{\circ} \mathrm{C}$.

a. The fusion profile was registered by cooling at $-60^{\circ} \mathrm{C}$ and heating at $10^{\circ} \mathrm{C} / \mathrm{min}$ to $90^{\circ} \mathrm{C}$.

b. The crystallization profile was registered by heating at $90^{\circ} \mathrm{C}$ for $10^{\circ} \mathrm{C} / \mathrm{min}$ and cooling at $10^{\circ} \mathrm{C} / \mathrm{min}$ to $-60^{\circ} \mathrm{C}$

c. The samples were heated at $90^{\circ} \mathrm{C}$, cooled at $-60^{\circ} \mathrm{C}$ for $10 \mathrm{~min}$ and then heated again at $10^{\circ} \mathrm{C} / \mathrm{min}$ to $90^{\circ} \mathrm{C}$ to register the profile and enthalpy fusion.

The fusion enthalpies required melt fat crystals in addition to the crystallization enthalpies required to solidify them. So, the enthalpies were calculated utilizing the area below the integration curve and the thermogram baselines. The temperature range of fusion and crystallization became clear in the curve at the onset and offset temperatures through phase changes [9].

\section{Slip Melting Point (SMP)}

This method was based on PORIM test no. p4.2 (1995). The samples were melted and filtered by a filter paper. Three clean capillary tubs were placed into the liquid samples completely, and the height of the oil in the capillary tubes was measured to be $10 \mathrm{~mm}$. As the ends of the filled tubes were held and rolled against a piece of ice, they were 
pressed, and the open end of the tubes was not allowed to touch the ice. The tubes were immediately cleaned with a piece of tissue paper. The tubes were held in a beaker of water, which was placed into a chiller filled with water at $10 \pm 0.1^{\circ} \mathrm{C}$. The test tubes were held for 16 $\mathrm{h}$ in the chiller. The capillary tubes were then removed from the test tube and attached with a rubber band to a thermometer such that the end of the tubes were level with the bottom of the mercury bulb of the thermometer. The thermometer was then suspended in a beaker containing $400 \mathrm{ml}$ of distilled water; the bottom of the thermometer was immersed in the water to depth of approximately $30 \mathrm{~mm}$. The starting temperature of the beaker was determined to be $5-10^{\circ} \mathrm{C}$ below the SMP, which was expected following the addition of ice. A magnetic stirrer was used for agitating the beaker. The rate of temperature increase was approximately $1 \pm 0.1^{\circ} \mathrm{C}$ per minute. Heating was continued until the fat column rose in each tube. The temperature of the water bath for each column rise was recorded, and the average of the all tubes was calculated.

\section{Iodine Value (IV)}

The number of grams of iodine absorbed by $100 \mathrm{~g}$ of fat under the test condition is expressed as the Iodine Value, according to PORIM test method no. p3.2, (1995). Halogen was added to potassium iodide, and titration with standard sodium thiosulphate $(0.1 \mathrm{~N})$ and a starch solution as the indicator was carried out. The blend samples were melted at $70-80^{\circ} \mathrm{C}$ and completely homogenized. The samples were weighed to the nearest $0.0001 \mathrm{~g}$ in a glass weighing vial. The vial was placed in a $500 \mathrm{ml}$ flask. To dissolve the fat, $15 \mathrm{ml}$ of carbon tetrachloride was added to each flask. Exactly $25 \mathrm{ml}$ of Wijs solution was added while the flask was gently shaken and placed in the dark for $1 \mathrm{~h}$. After wards, $20 \mathrm{ml}$ of potassium iodide solution and $15 \mathrm{ml}$ of water were added to the titration solution with sodium thiosulphate $(0.1 \mathrm{~N})$ until the yellow color due to iodine almost disappeared. Then, $1-2 \mathrm{ml}$ of starch indicator solution was added before titration continued until the blue color disappeared after vigorous shaking. Two determinations as well as a blank test were carried out under the same conditions.

\section{Saponification Value (SV)}

The number of milligrams of potassium hydroxide required to saponifyl $\mathrm{g}$ of sample under the conditions specified in PORIM test no. p3.1 (1995) is the saponification value (SV). The average molecular weight of all of the fatty acids present in the sample was first calculated. The glycerides were broken down by alcoholic alkali, and any free fatty acids became neutralized. In the presence of an indicator, excess alkali was back titrated with hydrochloride acid. The samples were melted at $70-80^{\circ} \mathrm{C}$ and completely homogenized before the start of the test. They were then filtered through a dry filter paper to remove any impurities. The sample was weighed to the nearest $0.005 \mathrm{~g}$, and a test portion was placed in a conical flask so that the volume of hydrochloric acid used for the sample was approximately half of what was needed for the blank. The weight was approximately $2 \mathrm{~g} ; 25 \mathrm{ml}$ of ethanolic potassium hydroxide solution and some boiling aids were added. After connecting the reflux condenser, the mixture was boiled gently for at least $60 \mathrm{~min}$, and the contents of the flask were swirled from time to time. The flask and condenser cooled slightly before the inside of the condenser was washed with a small amount of distilled water. Then, $1 \mathrm{ml}$ of phenolphthalein solution was added, and titration with hydrochloric acid $(0.5 \mathrm{~N})$ continued until the pink color of the indicator disappeared. A blank was determined at the same time.

\section{Solid Fat Content (SFC)}

The solid fat content of the samples was determined using a Bruker Minispec Mq 20 NMR Analyser (Rheinstetten, Germany). All of the samples in NMR tubes were melted at $80^{\circ} \mathrm{C}$ and then held at $60^{\circ} \mathrm{C}$ for $30 \mathrm{~min}$. The samples were cooled at $0^{\circ} \mathrm{C}$ for $90 \mathrm{~min}$, held at $26.5^{\circ} \mathrm{C}$ for $40 \mathrm{~h}$ and then cooled again at $0^{\circ} \mathrm{C}$ for $90 \mathrm{~min}$. All of the samples were stabilized for $60 \mathrm{~min}$ at various temperatures $(10,20,25,30,35$ and $40^{\circ} \mathrm{C}$ ) before measuring the liquid signal of every sample [12].

\section{Statistical Analysis}

The values described in this paper are the means and standard deviations for three replicates. The statistical analysis was performed with Excel Version 8.0 software. Significance was defined as $\mathrm{P}<0.05$.

\section{Results and Discussion}

\section{Effect of MW pre-treatment on the extraction yield of MSO and substrate moisture}

The mango seeds had a moisture content of $67.2 \mathrm{gH}_{2} \mathrm{O} / 100 \mathrm{~g}$ sample and an oil content of $5.65 \mathrm{~g}$ oil $/ 100 \mathrm{~g}$ sample. Table 1 shows the yield of oil extracted from treated mango seeds compared to the initial oil content in the sample. The oil extraction yield of the mango seeds increased with the application of MW radiation. MW pretreatment at $300 \mathrm{~W}$ for $180 \mathrm{~s}$ resulted in $8.9 \%$ oil extracted, which is more than the untreated samples; the MW-treated samples had a lower moisture content that made the seed more brittle, leading to more tissue rupture and an increase in the amount of oil extracted through solvent extraction.

Figure 1 shows a comparison of the oil yields of MS exposed to

\begin{tabular}{|l|l|l|l|}
\hline Potency & Time(S) & Extraction yield (\%) & Moisture (\%) \\
\hline control & & $5.65 \pm 0.05$ & $67.2 \pm 0.1$ \\
\hline 300 & 70 & $6.16 \pm 0.15$ & $65.16 \pm 0.3$ \\
& 90 & $6.50 \pm 0.1$ & $64.2 \pm 0.36$ \\
& 130 & $6.93 \pm 0.15$ & $63.33 \pm 0.72$ \\
& 180 & $8.90 \pm 0.1$ & $60.36 \pm 0.73$ \\
\hline 450 & 70 & $6 \pm 0.1$ & $64 \pm 0.2$ \\
& 90 & $6.4 \pm 0.1$ & $62.6 \pm 0.45$ \\
& 130 & $7.1 \pm 0.1$ & $59.6 \pm 0.52$ \\
\hline & 180 & $-^{*}$ & - \\
\hline
\end{tabular}

*sample was burned at $450 \mathrm{~W}$ and $180 \mathrm{~s}$

Table 1: Oil extraction yield of mango seeds.



Figure 1: Oil yield of mango seeds exposed to $300 \mathrm{~W}$ and $450 \mathrm{~W}$ of microwave power for radiation times of $180,130,90$ and $70 \mathrm{~s}$. 
Citation: Momeny E, Rahmati S, Ramli N (2012) Effect of Microwave Pretreatment on the Oil Yield of Mango Seeds for the Synthesis of a Cocoa Butter Substitute. J Food Process Technol 3:164. doi:10.4172/2157-7110.1000164

Page 4 of 7

two microwave power levels ( 300 and $450 \mathrm{~W}$ ) for various radiation times (70, 90, 130 and $180 \mathrm{~s})$. The oil yield of the seed exposed to 300 $\mathrm{W}$ of microwave power for 180 seconds was the highest $(8.9 \%)$; it had the lowest percentage of moisture (60.36\%). The oil yield of the seed exposed to $450 \mathrm{~W}$ of microwave power for $130 \mathrm{~s}$ had the second highest percentage $(7.1 \%)$. Figure 2 shows the effect of radiation time on moisture content at 300 and $450 \mathrm{~W}$. Among the variables were investigated, only time had a significant effect on oil extraction yield $(\mathrm{p}<0.05)$

\section{Effect of MW pretreatment on the physicochemical characte- ristics of mango seed oil}

Oil purity can be checked by determining the acid value. Free fatty acids are not present in purified oil, but noticeable amounts of free fatty acids may be present in crude oils. This value remained relatively constant at $1.31 \mathrm{mgKOH} / \mathrm{g}$ oil for the untreated mango seeds and increased slightly to $1.66 \mathrm{mgKOH} / \mathrm{g}$ oil after treatment; this increase might have been due to the hydrolysis of triacylglycerol by MW [2].

The saponification value could be used to characterize the types of glycerides in the samples. Glycerides containing long chain fatty acids have lower SVs than those with shorter chain fatty acids. According to Table 2, the SV of the treated mango seed oil was 138.5, while the value for the untreated seeds was 151.5; so after treatment SV decreased, which was previously reported for two vegetable oils [13]: sunflower seed oil (194-188) and olive oil (196-184).

The iodine value of the untreated seed was $47.3 \mathrm{~g} \mathrm{I} / 100$ oil, while that of the MW treated seed was $50.7 \mathrm{~g} \mathrm{I} / 100$ oil; these values reflect the ability of unsaturated carbon to carbon bond to absorb halogen atoms. By increasing iodine value, slip melting point decreases. The slip melting point of the treated samples (18.13) was lower compared to the control. Therefore, both IV and SMP proved that the degree of unsaturation in the oil increased with pre-treatment.

The unsaponifiable matter of mango seed oil without any MW treatment and that of mango seed oil with MW treatment were $2.46 \%$ and $2.94 \%$, respectively; the increase may be due to the high content of hydrocarbons, sterols, triterphenols, carotenoid and tocopherols [2].

The peroxide value shows that oxidation reactions occurred due to transition metal irradiation and elevated temperatures that formed free radicals [14]. PV affects organoleptic flavors. The oxidation of oil seeds accelerates during microwave heating, which leads to the formation of reactive radicals [15]. This behavior was observed in this study in the mango seed oil; the PV of the oil increased to 1.3 meq $\mathrm{O}, \mathrm{kg}$ oil.

Table 3 presents the analytical results of GC-ME for the MSO and $\mathrm{CB}$ samples. Three main fatty acids that appear in the fatty acid profiles of both the MSO and CB samples are oleic, stearic and palmitic acids. In the MSO sample, the percentages of these fatty acids are 47.56, 30.39 and $13.79 \%$, respectively, while in the CB sample; the percentages are $33.35,37.37$, and $25.70 \%$, respectively. The percentages of these fatty acids in CB total more than $95 \%$. The origin of the cocoa bean can affect the percentage of acylglycerides, which vary between 80 and 95\% and include POP, POS and SOS (where P=Palmitic acid, O=Oleic acid, and $S=$ Stearic acid). The composition of triyacylglycerides in $\mathrm{CB}$ can provide unique physicochemical characteristics that determine its thermal behavior and phase conduct $[16,17]$.

Synthesis of cocoa butter substitute through enzymatic reaction between $\mathrm{MSO}$ and $\mathrm{CB}$

The determination of the slip melting point was necessary to

\begin{tabular}{|l|l|l|}
\hline Property & Untreated sample & Treated sample \\
\hline Refractive index $\left(28^{\circ}\right)$ & $1.46 \pm 0.01$ & $1.46 \pm 0.01$ \\
\hline Acid value & $1.31 \pm 0.01$ & $1.66 \pm 0.05$ \\
\hline Saponification value & $151.54 \pm 0.05$ & $138.5 \pm 0.5$ \\
\hline lodine value & $47.3 \pm 0.1$ & $50.7 \pm 0.2$ \\
\hline Unsaponification value (\%) & $2.46 \pm 0.05$ & $2.94 \pm 0.12$ \\
\hline Slip melting point & $20.56 \pm 0.4$ & $18.13 \pm 0.35$ \\
Peroxide value & $0.96 \pm 0.05$ & $1.3 \pm 0.1$ \\
\hline
\end{tabular}

Table 2: Physicochemical characteristics of mango seed oil.

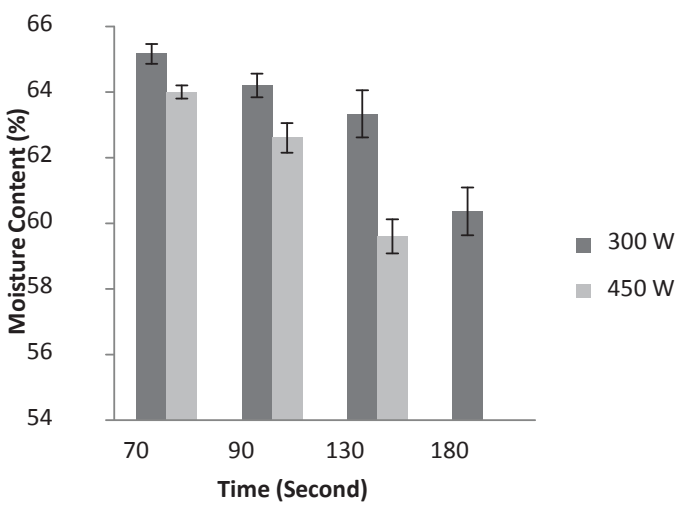

Figure 2: Moisture content of mango seeds exposed to 300 and $400 \mathrm{~W}$ of microwave power for radiation times of $180,130,90$ and $70 \mathrm{~s}$.

\begin{tabular}{|l|l|l|l|}
\hline Fatty acid & & MSO & CB \\
\hline Palmitic & C16:0 & 13.79 & 25.70 \\
\hline Stearic & C18:0 & 30.39 & 37.37 \\
\hline Oleic & C18:1 & 47.56 & 33.35 \\
\hline Linoleic & C18:2 & 5.623 & 2.30 \\
\hline Linolenic & C18:3 & 0.524 & 0.30 \\
\hline Arachidic & C20:0 & 1.382 & 1.01 \\
\hline Myristic & $14: 0$ & 0.83 & - \\
\hline Saturated fatty acids & 46.39 & 64.08 \\
\hline Unsaturated fatty acids & 53.7 & 35.95 \\
\hline Unsaturated/saturated & 1.15 & 0.56 \\
\hline
\end{tabular}

${ }^{a}$ Average of duplicate analysis.

Table 3: Profile of the fatty acids ain mango seed oil and cocoa butter.

\section{Slip Melting Point}

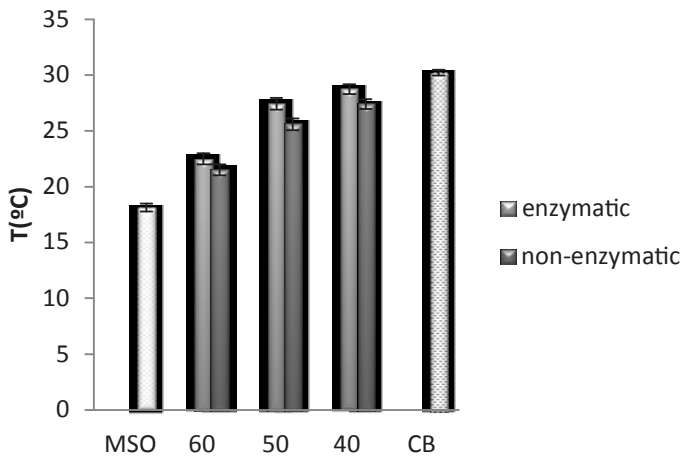

Figure 3: Slip melting points of the three blends that underwent enzymatic and non-enzymatic reactions, as well as MSO and CB. 
identify the fat blend that is most suitable to be a CBS. Table 4 shows the SMP for each blend before and after enzyme treatment. The 40:60 blend does not show any significant differences from $\mathrm{CB}$ after enzymatic reaction; the SMPs of the other blends are significantly different from $\mathrm{CB}(\mathrm{P}<0.05)$. Figure 3 shows comparisons between the SMP of the four blends that were subjected to enzymatic and non-enzymatic reactions.

According to table 5, pure $\mathrm{CB}$ had the highest saponification value (SV). As the amount of CB in the blends increased, SV increased proportionally. The SV of cocoa butter was not significantly different from the SV of the 40:60 blends that underwent enzymatic and nonenzymatic reactions. Figure 4 compares the SVs of the blends that were subjected to enzymatic and non-enzymatic reactions.

According to results shown in table 6, the IVs of all the mixtures, except the 40:60 blend that underwent enzymatic and non-enzymatic reactions, are significantly higher than the $\mathrm{CB}$ so the IV of cocoa butter was not significantly different from the IV of the 40:60 blends. Figure 5 shows comparisons of the IVs between the five blends.

In the plot of solid fat content (SFC) versus temperature in figures 6 and 7, the fat mixtures melting behavior between $0-40^{\circ} \mathrm{C}$ are shown, while the $40: 60$ blends melted between $25^{\circ} \mathrm{C}$ and $40^{\circ} \mathrm{C}$, similar to cocoa butter.

Table 7 shows the fusion and crystallization profiles for cocoa butter and the 40:60 MSO:CB blend. CB melted completely and was maintained at $90^{\circ} \mathrm{C}$ for $10 \mathrm{~min}$. The fusion and crystallization profiles for $\mathrm{CB}$ resembled the 40:60 MSO: CB blend. Based on figure 8, CB has two maxima fusions at $12.60^{\circ} \mathrm{C}$ and $30.51^{\circ} \mathrm{C}$. The $\Delta H_{\mathrm{f}}$ for cocoa butter was $73.3 \mathrm{~J} / \mathrm{g}$; crystallization began at $16.31^{\circ} \mathrm{C}$ and reached its maximum point at $10.61^{\circ} \mathrm{C}$. The $\Delta H_{c}$ for cocoa butter was $84.86 \mathrm{~J} / \mathrm{g}$.

According to figure 9, the MSO:CB blend had two maximum fusion points at $13.78^{\circ} \mathrm{C}$ and $30.15^{\circ} \mathrm{C}$. The $\Delta H_{\mathrm{f}}$ for this blend was 77.04 $\mathrm{J} / \mathrm{g}$. The cooling process started at $18.73^{\circ} \mathrm{C}$ and ended at $-52.55^{\circ} \mathrm{C}$, with a crystallization maximum at $16.23^{\circ} \mathrm{C}$. The $\Delta H$ for the solidification of this blend was $89.74 \mathrm{~J} / \mathrm{g}$.

Three main crystalline forms exist in vegetable lipids: $\alpha, \beta^{\prime}$, and $\beta$. Polymorph $\alpha$, with the lowest fusion point, is produced after a quick cooling process. The $\beta^{\prime}$ form is produced from the transition of the a form, which has a higher melting point, under particular conditions through solidification. The most stable crystalline form is $\beta$, which is

\begin{tabular}{|l|l|l|}
\hline Blends & SMP $\left({ }^{\circ} \mathbf{C}\right)$ Enzymatic reaction & SMP $\left({ }^{\circ} \mathbf{C}\right)$ control \\
\hline MSO $(100: 0)$ & $18.13 \pm 0.35^{\mathrm{e}}$ & $18.13 \pm 0.35^{\mathrm{e}}$ \\
\hline $60: 40$ & $22.5 \pm 0.5^{\mathrm{d}}$ & $21.5 \pm 0.5^{\mathrm{d}}$ \\
\hline $50: 50$ & $27.43 \pm 0.4^{\mathrm{c}}$ & $25.59 \pm 0.52^{\mathrm{c}}$ \\
\hline $40: 60$ & $28.75 \pm 0.25^{\mathrm{b}}$ & $27.41 \pm 0.44^{\mathrm{b}}$ \\
\hline CB $(0: 100)$ & $30.23 \pm 0.25^{\mathrm{a}}$ & $30.23 \pm 0.25^{\mathrm{a}}$ \\
\hline
\end{tabular}

Note: * values represent the average of triplicates \pm standard deviation (SD).

Table 4: Slip melting point ${ }^{*}\left({ }^{\circ} \mathrm{C}\right)$ of the mixtures and cocoa butter.

\begin{tabular}{|l|l|l|}
\hline Blends & SV $(\mathbf{m g ~ K O H} / \mathbf{g}$ oil) Enzymatic reaction & $\mathbf{S V}(\mathbf{m g ~ K O H} / \mathbf{g}$ oil) control \\
\hline $\begin{array}{l}\text { MSO } \\
(100: 0)\end{array}$ & $138.52 \pm 0.5^{\mathrm{e}}$ & $138.52 \pm 0.5^{\mathrm{e}}$ \\
\hline $60: 40$ & $160.06 \pm 0.2^{\mathrm{d}}$ & $166.48 \pm 0.38^{\mathrm{d}}$ \\
\hline $50: 50$ & $178.4 \pm 0.45^{\mathrm{c}}$ & $175.64 \pm 0.52^{\mathrm{c}}$ \\
\hline $40: 60$ & $186.8 \pm 0.6 \mathrm{~b}$ & $186.63 \pm 0.38^{\mathrm{b}}$ \\
\hline $\begin{array}{l}\mathrm{CB} \\
(0: 100)\end{array}$ & $188.75 \pm 0.23^{\mathrm{a}}$ & $188.75 \pm 0.23^{\mathrm{a}}$ \\
\hline
\end{tabular}

Note: * values represent the average of triplicates \pm standard deviation (SD).

Table 5: Saponification values * (SV) of the mixtures and cocoa butter.

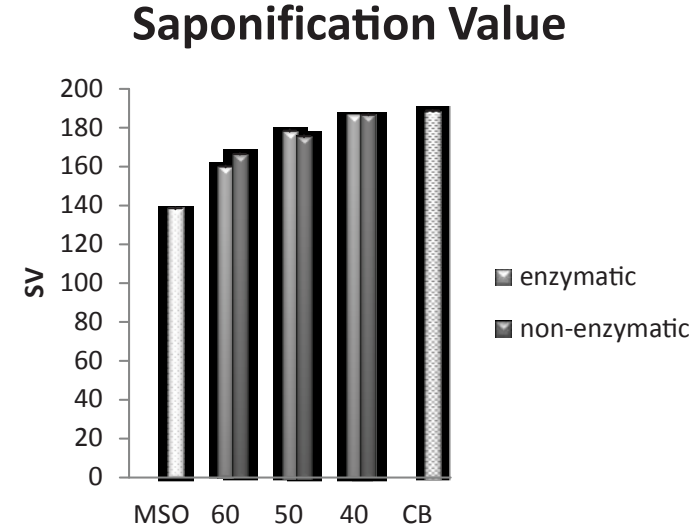

Figure 4: The saponification values of the three blends that were subjected to enzymatic and non-enzymatic reactions, as well as MSO and CB.

\begin{tabular}{|l|l|l|}
\hline Blends & $\begin{array}{l}\text { IV (g I 2/ 100 g oil) Enzymatic } \\
\text { reaction }\end{array}$ & IV (g I 2/ 100 g oil) Control \\
\hline MSO (100:0) & $50.7 \pm 0.29^{\mathrm{a}}$ & $50.7 \pm 0.2^{\mathrm{a}}$ \\
\hline $60: 40$ & $42.43 \pm 0.4^{\mathrm{b}}$ & $43.34 \pm 0.32^{\mathrm{b}}$ \\
\hline $50: 50$ & $39.54 \pm 0.13^{\mathrm{c}}$ & $39.62 \pm 0.16^{\mathrm{c}}$ \\
\hline $40: 60$ & $36.3 \pm 0.4^{\mathrm{d}}$ & $36.56 \pm 0.38^{\mathrm{d}}$ \\
\hline $\mathrm{CB}(0: 100)$ & $34.13 \pm 0.32^{\mathrm{e}}$ & $34.13 \pm 0.32^{\mathrm{e}}$ \\
\hline
\end{tabular}

Note: * values represent the average of triplicates \pm standard deviation (SD)

Table 6: lodine value* (IV) of the mixtures, MSO, and CB.

\section{lodine Value}

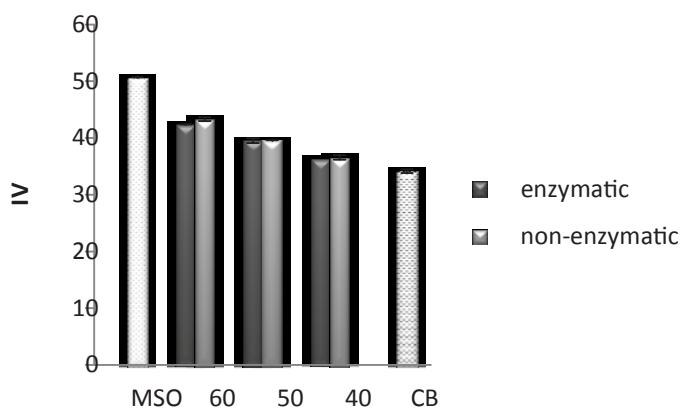

Figure 5: The iodine values of $\mathrm{MSO}, \mathrm{CB}$, and the three blends that were subjected to enzymatic and non- enzymatic reaction.

\begin{tabular}{|c|c|c|c|c|c|c|}
\hline \multirow[t]{2}{*}{ samples } & \multirow[t]{3}{*}{$\Delta \mathrm{H}(\mathrm{J} / \mathrm{g})$} & \multicolumn{5}{|c|}{ Transition temperature $\left({ }^{\circ} \mathrm{C}\right)$} \\
\hline & & 1 & 2 & 3 & 4 & 5 \\
\hline \multicolumn{6}{|l|}{ crystallization } & \\
\hline MSO: CB $\{40: 60\}$ & 89.74 & 18.73 & 16.23 & -30.54 & -40.99 & -52.55 \\
\hline CB & 84.86 & 16.31 & 10.61 & -21.22 & -32.17 & n.d. \\
\hline \multicolumn{7}{|l|}{ Fusion } \\
\hline MSO:CB $\{40: 60\}$ & 77.04 & -8.72 & 13.78 & 24. 79 & 30.15 & 45.56 \\
\hline CB & 73.35 & -10.02 & 12.60 & 22.03 & 30.51 & 46.47 \\
\hline
\end{tabular}

Table 7: The transition point temperatures and crystallization and fusion enthalpies for MSO:CB blends and CB.

generated from $\alpha$ and $\beta^{\prime}$. The $ß$ form has the highest fusion point [18]. According to figures 8 and 9, the thermal behavior of the 40:60 MSO: $\mathrm{CB}$ blend and $\mathrm{CB}$ were similar and the curves for solid-liquid change were relatively simple and presented resemblance to those of CB. 
Citation: Momeny E, Rahmati S, Ramli N (2012) Effect of Microwave Pretreatment on the Oil Yield of Mango Seeds for the Synthesis of a Cocoa Butter Substitute. J Food Process Technol 3:164. doi:10.4172/2157-7110.1000164

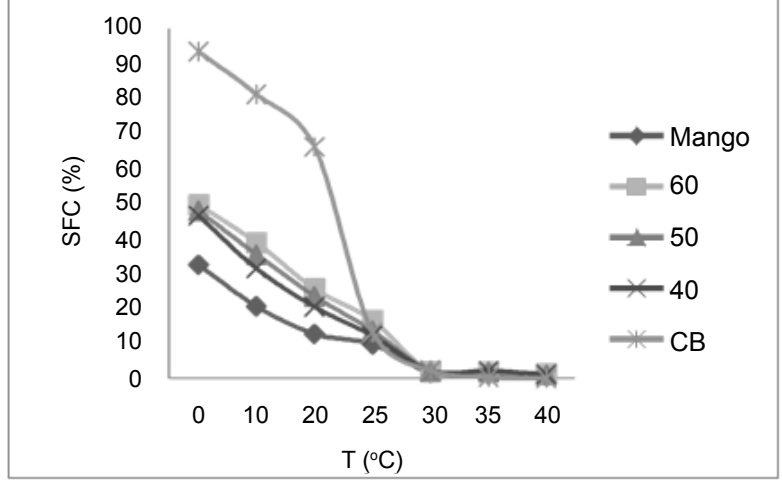

Note: *each mixture line represents the average of triplicates

Figure 6: Solid fat content * $(\%)$ of fat mixtures subjected to enzymatic reactions.

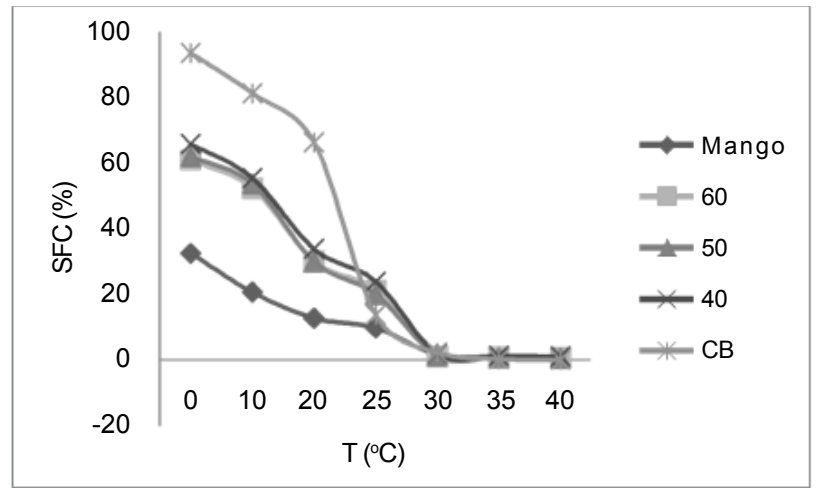

Note: *each mixture line represents the average of triplicates

Figure 7: Solid fat content * $(\%)$ of fat mixtures subjected to non-enzymatic reactions.

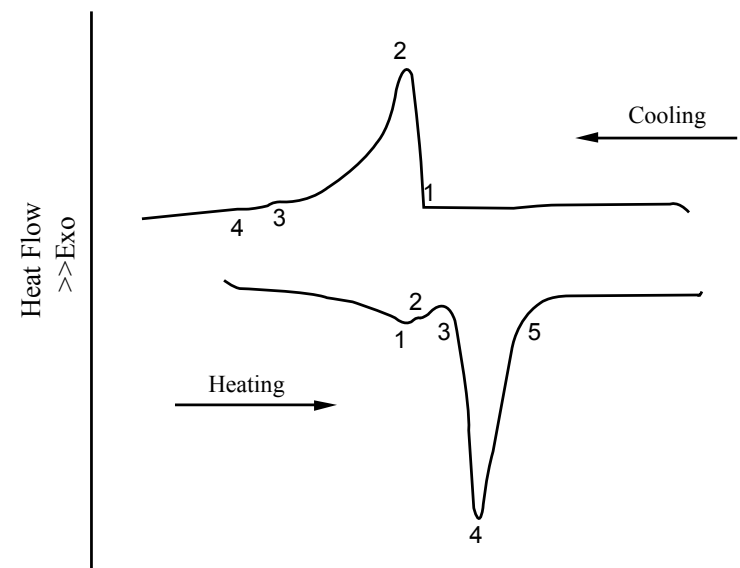

Figure 8: Crystallization and fusion curves for CB. Refer to Table 7 for labels $1-5$

\section{Conclusion}

This study showed that microwave pretreatment before conventional extraction increased oil yield to $8.9 \%$. MW pretreatment

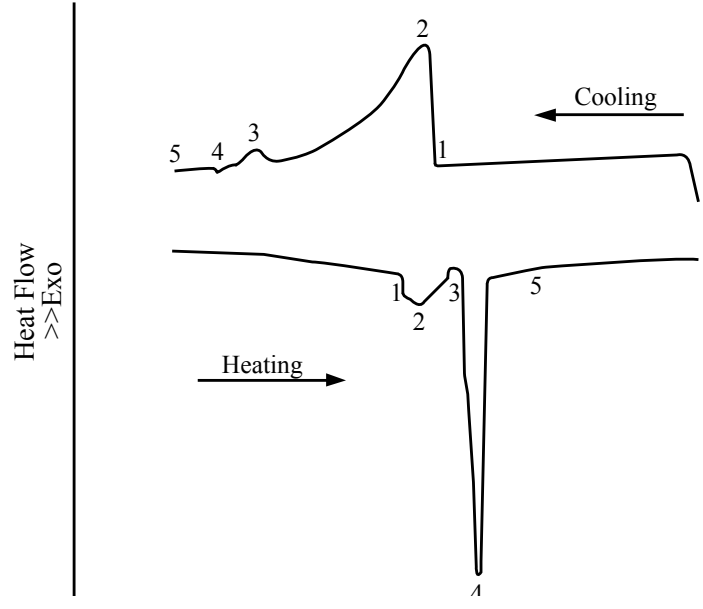

Figure 9: Crystallization and fusion curves for the 40:60 MSO: CB blend. Refer to Table 7 for the labeled transition temperatures (1, 2, 3, 4 and 5).

caused microstructural modification of the substrate tissue, increase in mass transfer of oils and unsaponification value in extracted oil. MW pretreatment helps in rapture of the cell wall and making cell permeabilization possible and enabling the oil move through the permeable cell walls. The blending of MSO and CB in three different ratios was carried out to determine which blend exhibited characteristics most similar to cocoa butter. The 40:60 MSO: CB blend had the closest SMP to CB and SV and IV that were not significantly different from $\mathrm{CB}$; the SFC from $25^{\circ} \mathrm{C}$ to $40^{\circ} \mathrm{C}$ was closest to $\mathrm{CB}$. In addition, the solid-liquid change of the 40:60 MSO: CB blend closely resembled $\mathrm{CB}$, which reflects the presence of the $\alpha$ and $\beta^{\prime}$ crystalline forms that constitute the $\beta$ form as in $\mathrm{CB}$. Thus, this blend is suitable for use in chocolate and confectionery applications due to its consistency and other characteristics.

\section{References}

1. Azadmard-Damirchi S, Alirezalu K, Fathi Achachlouei B (2011) Microwave Pretreatment of Seeds to extract high quality vegetable oil. World academy of science, engineering and technology.

2. Uquiche $\mathrm{E}$, Jerez $\mathrm{M}$, Ortiz J (2008) Effect of pretreatment with microwave on mechanical extraction yield and quality of vegetable oil from Chilean hazelnuts (Gevuina avallana Mol). Innovative Food Science \& Emerging Technologies 9: 495-500.

3. Wang L, Weller CL (2006) Recent advances in extraction of nutraceuticals from plants. Trends Food Sci Technol 17: 300-312.

4. Hai-Xoing Wang HW, Chi-Tang Ho, Xin-Chu Weng (2006) Cocoa butter equivalent from enzymatic interestrification of tea seed oil and fatty acid methyl esters. Food chemistry 97: 661-665.

5. Daniel Undurraga AM, Sonia Erazo (2001) Cocoa butter equivalent through enzymatic interestrification of palm oil mid fraction. Process Biochemistry 36 933-939.

6. Uzoma K (2011) Mango Seed Extract for Weight Loss.

7. Ashoush IS, Gadallah MGE (2011) Utilization of mango peels and seed kerne powders as sources of phytochemicals in biscuit. World Journal of Dairy \& Food Science 6: 35-42.

8. Vivekananda M, Yogesh M, Hemalatha S (2007) Microwave Assisted Extraction-An Innovative and Promising Extraction Tool for Medicinal Plan Research. Pharmacognosy Reviews 1: 7-18.

9. Solís-Fuentes JA, Durán-de-Bazúa MC (2004) Mango seed uses: therma behaviour of mango seed almond fat and its mixtures with cocoa butter. Bioresour Technol 92: 71-78. 
Citation: Momeny E, Rahmati S, Ramli N (2012) Effect of Microwave Pretreatment on the Oil Yield of Mango Seeds for the Synthesis of a Cocoa Butter Substitute. J Food Process Technol 3:164. doi:10.4172/2157-7110.1000164

10. Macrae AR (1983) Lipase catalysed inter-esterification of oil and fats. J Am Oil Chem SOC 60: 291-294.

11. Abdalla AEM, Darwish SM, Ayad EHE, El- Hamahmy RM (2007) Egyptian mango by-product 1. Compositional quality of mango seed kernel. Food chemistry 103: 1134-1140.

12. Soekopitojo S, Hariyadi P, Muchtadi TR, Andarwulan N (2009) Enzymatic interestrification of palm oil mid fraction blend for production of cocoa butter equivalent. Asian Journal of Food and Agro-Industry 2: 807-816.

13. Nichols DS, Sanderson K (2003) The nomenclature, structure, and properties of food lipids. chemical and functional properties of food lipids. Boca Raton, FL: CRS Press LLC.

14. Decker EA (1998) Antioxidant mechanisms. Food lipids chemistry, nutrition, and biotechnology. Marcel Dekker, New York.

15. Farag RS, Hewedi, F.M., Abu-Raiia, S.H \& Elbaroty, G.C (1992) Comperative study on the deterioration of oils by microwave and conventional heating. Journal of food protection 55:722-727.
16. Talbot G (1995) Fat eutectics and crystallisation. In: Beckett ST (ed) physicochemical aspects of food processing blackie academic and professional Chapman and Hal, Landon.

17. Timms RE (1980) The phase behaviour of mixtures of cocoa butter and milk fat. Lebensm Wiss Technol 13: 61-65.

18. Hageman JW (1988) Thermal behavior and polymorphism of acylglycerides. In Garti N, Sato, K (ed) Crystallization and Polymorphism of Fats and Fatty Acids, vol 31. Marcel Dekker, New York.

19. Barnes PJ (1983) Non -saponifiable lipids in cereals. lipids in cereal technology. Academic Press, New York.

20. O'Brien RD (2004) Fats and oils. Formulating and processing for application 2nd edn. CRC Press LCC.

21. PORIM (1995) Palm Oil Research Institute of Malaysia (PRIM) test methods. Kuala Lumpur. 